\title{
CHRISTOPH MEINEL
}

\section{EMPIRICAL SUPPORT FOR THE CORPUSCULAR THEORY IN THE SEVENTEENTH CENTURY}

\section{INTRODUCTION}

The purpose of this paper is to evaluate the empirical content and experimental foundation of the early seventeenth-century corpuscular hypothesis. Supported by ontological, epistemological, and mathematical arguments, observational and experimental evidence played an important part in creating those patterns of thought that were instrumental in the transformation and, eventually, acceptance of the corpuscular theory of matter.

Compared to the rise of astronomy and mechanics, the success of seventeenth-century atomism is ambiguous. Unlike other physical theories of the time the atomic doctrine was not based on experiments likely to be accepted by today's scientific standards. In Galileo's inclined plane and his law of falling bodies or in Newton's theory of colors and his experimentum crucis with the prism, for example, theory and experiment, observation and conclusion were connected in a way still acceptable to us. In atomism, however, this is not the case, although almost all corpuscular theories of the seventeenth century explicitly claimed to be derived from and based upon experience. Yet, it was not until the nineteenth century that experimental results made the atoms at least plausible.

The difficult relationship between seventeenth century atomism and its experimental foundation has been obscured to some extent by later historians. When the standard histories of atomism were written at the end of the nineteenth century ${ }^{1}$, a final experimental confirmation of the corpuscular nature of matter was still lacking. Twentieth-century historians, on the other hand, have underestimated the empirical difficulties involved in early modern atomism.2 Knowing that there are atoms in nature, they could hardly imagine how the protagonists of the scientific revolution should not have arrived at this same conclusion. 


\section{EXPERIENCE AND EXPERIMENTS}

The empirical arguments presented to support atomism during the first half of the seventeenth century were mainly based upon five groups of phenomena:

1. Extrapolations from macroscopic bodies;

2. observations by means of the microscope;

3. transport processes such as evaporation, abrasion or growth;

4. condensation and rarefaction including the question of the vacuum;

5. chemical processes such as reductions of metals.

\subsection{Extrapolations}

Traditional arguments put forward - for the first time in antiquity and most of them in Lucretius' De rerum natura - were extrapolations. The most frequently quoted example was the one of insects which are so small that their third part would already be beyond the limits of visibility. How small then, Lucretius asked, must their organs be, and how small, in the end, the atoms out of which everything is composed? ${ }^{3}$

Originally aimed at giving but an idea of atomic dimensions, the observation was quoted frequently in order to prove their very existence. On a similar level lies the comparison of the atoms to the size of tiny motes one sees dancing back and forth when a ray of sunlight falls in a dark room. ${ }^{4}$ In either case the empirical facts referred to were loci classici from a literary tradition of figurative use of pictures, aimed at creating astonishment and, through astonishment, assent and persuasion.

Authors scarcely expanded on these examples; they simply quoted them. In 1643 Claude Bérigard presented a carefully designed experimental verification of Lucretius' motes in the sunbeam. ${ }^{5}$ To exclude the possibility that the phenomenon was caused by major particles such as normal dust, he sealed a glass vessel and kept it quiet for a long time making sure that all dust had settled. The minute reflecting particles he observed nevertheless inside the glass were consequently judged to be the atoms themselves.

Among those to make the first, if cautious, steps towards a quantitative determination of atomic dimensions was Daniel Sennert in 1636. In a series of experiments ${ }^{6}$ designed to prove the existence of atoms Sennert described a distillation in which a stream of alcohol vapor passed through a sheet of paper, the density of which was supposed to give an idea of how small the atoms really were. This certainly was an impressive experiment, but at the same time a tacit reference to Lucretius.7 Sennert went on to give 
examples of various distillations, comparing the enormous volume of vapor and the myriads of atoms in it to the small droplets into which they condense, or the smoky wick of an extinguished candle to the huge volume of air that was filled by its smoke.

The language in which these observations were described abounds with quantitative statements such as to the duration of the experiment, the number of corpuscles, the amount of the product, and the size of the candle-wick. However, it is clear that there was no quantitative methodology behind these indications. Sennert used the language of the laboratory in a merely figurative and persuasive manner, appealing to the imagination of the reader.

On the basis of impressive calculations Johann Magnenus even suggested exact figures for the size of an atom. ${ }^{8}$ But what does it prove for the result computed in such a way to come surprisingly close to modern figures? Were such calculations really quantitative science or merely a scholarly variation of a theme from Archimedes' The Sand-Reckoner? Playing with numbers seemed quite common, indeed. In 1654 Walter Charleton published exactly the same calculation', though at least he should have been aware of the warnings by his admired hero Gassendi: Referring to Archimedes' attempts to compute the number of sand grains that fit into a poppy-seed, the French philosopher had already pinpointed the methodological problems involved in transferring this kind of geometric reasoning to physical matters.10

However, since Magnenus' calculations have been recently called the beginning of the quantitative methodology in atomic physics"1, it might be worth while examining more closely the attitude of this allegedly scientific mind towards experience and experiment. There is no doubt that Magnenus favored the empirical and mechanical spirit of his age; nevertheless his work abounds with purely dialectical reasoning and syllogistic conclusions. The only 'real' experiment he presented in great detail was taken from a popular compendium of natural magic12: According to Quercetanus ${ }^{13}$ a Polish physician was reported to keep a collection of sealed glass vessels containing finely ground flowers of various kinds. When a candle was put underneath the vessel the corpuscles coalesced under the influence of heat to form a perfect blossoming plant. When the candle was removed, it again disintegrated. This strange experiment acquired some fame among the attempts of proving the reality of the atoms and was discussed even among the most respectable scientists of that time.14 Needless to say, this was not the kind of experiment upon which a scientific atomism could have been properly established. 


\subsection{Microscopical Perception}

Seventeenth-century science was fond of the small, the worlds to be found in a drop of water. There was a widespread enthusiasm for the magnifying glass and for the microscope which had just been invented. The new instruments made it possible to come closer to the details, closer to reality, and - so it was assumed - closer to truth. The possibilities of optical ingenuity seemed unlimited. In a chapter on the size of the atoms Gassendi thoughtfully meditated about what degree of refinement the borderline between man's and nature's subtlety might be extended to by the use of the microscope. ${ }^{15}$

What had been a merely potential aptitude of the instrument to Gassendi, was presented as an empirical fact by Henry Power a few years later. His Experimental Philosophy, the first English book on microscopy, claimed enthusiastically that the microscope enabled men to "see what the illustrious wits of the Atomical and Corpuscularian Philosophers durst but imagine, even the very Atoms and their reputed Indivisibles and least realities of Matter."16 This was more than the selling rhetoric so common with prefaces. Power studied traces of mercury and found that the "atoms of Quick-silver [ ... ] seemed like a globular Looking-glass"17. From the heterogeneity and particulate structure of a cosmetical precipitate, he inferred that "all the globular Atoms of current and quick [mercury]; besprinkled all amongst those Powders, like so many little Stars in the Firmament" remain unaltered when a compound is formed and retain their true nature. ${ }^{18}$

As a serious scientist, however, Power had to admit that he failed to succeed in seeing any corporeal effluvia by means of his optical device, although others had claimed to have seen the magnetic effluvium. Power, the meticulous observer, was convinced that such an observation "indeed would be an incomparable Eviction of the Corporeity of [ ... ] Effluviums, and sensibly decide the Controversy "twixt the Peripatetic and Atomical Philosophers"19.

Stimulating as these instruments were for the study of biology, their meaning remained ambiguous in matter theory. Joachim Jungius used the magnifying glass for a thorough study of apparently homogeneous substances. He observed that they were in fact always heterogeneous if viewed through a microscope, and no surface could be so smooth that one could not think of a more powerful microscope that would reveal its real discontinuity. Consequently, Jungius stated that continuity must be exempt from the jurisdiction of sensuous experience. On the other hand, if there were no truly continuous parts in the end, endless progression and divisibility would result.20 This was the vicious circle of every 
empirical approach to the atoms. Since they are so small that they could be inferred only rationally, methodological difficulties and a contradictory epistemology arose if one attempted to model the real after the visible.

\subsection{Material Transport}

Transport phenomena in which material substances appear or disappear invisibly provided a similar type of argument: Smell is an efflux of corporeal particles and comes to an end once its material source is exhausted.21 Clothes hung near the seashore become wet and dry again in the sunshine.22 The drying of bread or the slow evaporation of liquids are material processes, although the flux of material cannot be observed. In all these cases, quantitative change can be recorded, and from this the existence of invisible parts of matter could be inferred. Yet, this was not a very original conclusion, but rather an application of the theory of effluxion proposed by Empedocles, empirically founded by Democritus and Asclepiades of Prusa and eventually collected in Lucretius' poem. In the seventeenth century these examples were repeated over and over again, and similar ones were added.

It is hard to believe that this kind of naive realism was taken more seriously than we can take it with regard to the question of atoms. Three aspects should be given particular consideration: the phenomena dealt with so far suggested that the ultimate constituents of matter were (i) potentially observable by extended experimental effort, (ii) deductible by analogy, and (iii) provable by virtue of their actions. Yet there is little doubt that they were not suitable to definitively decide the question of matter, and they were certainly not understood in this manner by the contemporaries. The frequent occurrence and repetition of these observations, however, the persuasive idea that truth should be visible or could be thought of in a pictorial way infiltrated the scholarly discourse and the very language of science. In the end the idea of little particles as constituent parts of bodies became plausible, even though philosophically not entirely legitimate. Furthermore, and this was of no less importance, it transferred the corpuscular question to another level of inquiry. For now it became necessary to prove the material identity of these particles. This was, of course, a chemical question, but we have to deal with the more physical arguments first before we return to chemistry. 


\subsection{Condensation and Rarefaction}

Unlike the instances of naive induction from sense perception dealt with so far, condensation and rarefaction and, above all, the vacuum, belong to a field of physical experimentation where one would expect more convincing departures from the traditional ways of reasoning. In ancient atomism, with its hard and impenetrable atoms, change required motion, and motion required a void space to move into. The nature of this void, however, was a matter of endless controversies until the eighteenth century. ${ }^{23}$ Two alternatives had already been discussed by the Greeks: the continuous or three-dimensionally extended void and, secondly, the more widely received idea of a discontinuous, interspersed void between the particles of matter.

There was one classical experiment that used to be interpreted as evidence supporting the existence of microvacua: A vessel filled with loose ashes holds as much water as the empty vessel, because the tiny ash particles are received within the pores or vacua of the water. The observation was reported by Aristotle24, referring to those who believed in the void, but was rejected on the ground that two bodies cannot occupy the same space simultaneously. This was indeed puzzling and kept the medieval commentators busy. Francis Bacon was presumably the first to disprove the phenomenon in question experimentally. ${ }^{25}$

In reality, things were not as simple. In Gassendi's Syntagma philosophicum the ash experiment was rejected on both experimental and philosophical grounds. ${ }^{26}$ Instead, the French philosopher proposed another and more convincing experiment. He took water, saturated with ordinary salt, and found that this solution was still as capable of dissolving alum as pure water would have been. ${ }^{27}$ From this Gassendi concluded that there must be various differently shaped microvacua in the water, each kind of which receives exactly one kind of corpuscles, e.g. a cubic space a cubic corpuscle such as salt, and an octaedric space an octaedric one such as alum. But wasn't it absurd to assume that the volume remained constant when another volume was added? This is exactly what Gassendi's carping critic Jean-Baptiste Morin thought. He repeated the experiment more carefully in a glass flask with a graduated neck and found that when salt, alum, and sugar were added to water, the volume of the resulting solution was greater than that of pure water.28 From textual evidence alone, it is difficult to judge who was correct. In fact, either observation may have been correct: There are indeed certain salts that do not increase the volume of water when they are dissolved, and water-free alum is one of them. 
Apart from explaining solution, the hypothesis of interparticulate vacua seemed especially helpful in understanding coherence. The standard experiment was the separation of two entirely flat surfaces from direct contact in order to show that during this process a void must result since the air cannot fill the entire space opened instantaneously.29 Though originally supposed to prove the existence of a vacuum, the experiment soon acquired a crucial position among the proofs for its non-existence. It was still in this sense that Galileo, who rejected the extended void, referred to it as a perfect illustration for nature's abhorrescence of a vacuum. ${ }^{30} \mathrm{He}$ described a hydrostatic experiment designed to measure the breaking force of a water column that would give him a quantitative value for what he called la resistenza del vacuo.31 It was exactly this "resistance of the vacuum" which he believed to be responsible for the strength and rupture tension of solid bodies.

The problem of coherence and the void became even more acute in condensation and rarefaction. The Aristotelian explanation was, that a given amount of matter could assume, at different times, contrary qualities; and since dense and rare were contrary qualities, the same amount of matter could occupy different volumes at different times while maintaining its identity through the changing modes of its existence. ${ }^{32}$ Indeed no corpuscular explanation of a similar smoothness was available. Few authors would have admitted that the interspersed vacua could be blown up to a size that would account for the observed change of volume during evaporation. Otherwise, they would have had to admit a continuous vacuum. It is well known that, even after the Torricellian vacuum had been experimentally demonstrated in 1643 , it was by no means unanimously considered to be entirely void. The first atomist to discuss the Torricellian experiment in great depth was presumably Gassendi; but even his account on the vacuum remained vague as to its meaning in theory of matter. ${ }^{33}$

Instead of admitting the void, most authors assumed some kind of ether or spirit that filled the spaces between the vapor atoms and glued the corpuscles of solid bodies together. Yet, the reintroduction of an active spirit or ether into atomism, aimed at explaining how the atoms interact and how their actions are transmitted, undermined the theoretical consistency of the mechanical corpuscularianism, while the question of change and motion remained, however relegated to a somewhat lower level. Plenist corpuscular theories such as Descartes'34 exemplify that it was entirely acceptable to assume corpuscles without admitting the void. 


\subsection{Chemical Change}

The chemical arguments in support of the atomic view of matter refer to two kinds of phenomena: Processes generating a new mixtum, or processes recovering constituents of a compound in their former state. In both cases it was to be explained how distinct atomic particles interact and how, from this interaction, new qualities emerge that were not originally present in the reactants. The emergence or eduction of a new form during substantial alterations was indeed the great theme of early seventeenthcentury peripatetic theory of matter. ${ }^{35}$ Here purely mechanical action, and especially local motion, was not a sufficient explanation. Therefore additional hypotheses came into play which did not originally belong to, or were even contradictory to, the principles of atomism, such as the corporeal ether, active spirits, neoplatonic concepts of sympathy and antipathy, or the teleology of directing forms acting upon moving particles.

On the other hand, there was the old tradition of metallurgists and practical chemists who ignored such abstract questions and naively took the original reactants and their properties as the true constituents of a compound.36 It is significant that Sennert explicitly admitted that there was no way of proving the mechanism by which the unity of parts was effectuated and the form of the new compound generated.37 Practical chemist as he was, Sennert preferred to leave such questions to others, and went on to argue that at least one thing was certain, namely that every mixture could be resolved into those parts of which it was originally constituted. For, if the identity of the constituent parts was not constant, there would be a generation of new constituents during the process of resolution and decay.

of course, this was a tautology and depended on how one defines 'constituent part'. Yet, it was an important step within the 'chemical' argumentation in favour of corpuscles. For now, it was no longer necessary to bother with substantial change and the emergence of new qualities; instead, the question was reduced to a test of identity in a cyclic process. Once the identity of the original reactants and the final product could be demonstrated experimentally, the persistency of substantial identity in a material carrier would be proved, no matter how many alterations had occurred between the starting and final substances. This was clearly a departure from the former preoccupation with the quiddity of processes, and from the ontological level of the atomic theory to something that might be called a 'black box theory' of chemical change. 


\subsubsection{Reduction}

There is ample evidence that the ground for this new perspective had been laid by the pragmatism and the atheoretical attitude of metallurgists and iatrochemists. However, such people were hardly literate and rarely uttered their theoretical assumptions. Angelus Sala, court physician, pharmacist, and advisor on commercial subjects, described pragmatically and to some extent also quantitatively the formation and decomposition of copper vitriol. ${ }^{38}$ In doing so he distinguished, as usual, between transmutations and changes that resulted from a mere juxtaposition of particles. These latter processes were either coniunctiones, such as the alloying of gold and silver, or reductiones by means of which little particles were reassembled into their former coherent state. ${ }^{39}$ The best example was a solution of gold in aqua regia and its precipitation using metallic silver, a process which Sala considered a mere division and rearrangement of metal atoms. He believed the metal to retain its substantial identity, though "hidden" because of its dispersion into single atoms. As a practitioner Sala did not bother with the nature of this "hiding" of qualities; instead he accepted the reduction to the pristine metallic state as sufficient proof of the identity of gold throughout this process.

Daniel Sennert, on the other hand, the learned professor of medicine, preferred to maintain the teleology of directing forms to account for the specific properties. Expanding on Sala's approach he conceived a more convincing argumentation, based upon a great variety of processes which he classified as reductions to the pristine state.40 The first type were simple distillations and sublimations of substances such as alcohol, sulphuric acid, and sulphur, which he regarded to be merely mechanical operations by means of which bodies were mashed into their atoms.

A chemically more sophisticated argument came from the reduction of different mercury compounds to running mercurium vivum. In order to prove that, indeed, real atoms of mercury were involved and not just new substantial forms generated, Sennert referred to the nightmares of Paracelsian medication: Ointments and fumigations with mercury had the effect that a coin, put in the patient's mouth, became amalgamated - not to mention the findings of a postmortem autopsy. In all these examples the reduction to the pristine state was the decisive criterion.

The same is true for another type of experiment presented to prove that it was not the substantial form of a mixture that preserved the identity of its compounds, but in fact the atoms themselves ${ }^{41}$ : Sennert fused gold and silver together to obtain an 
entirely homogeneous alloy. Then he poured aqua fortis or nitric acid on it. The silver was dissolved, whereas the gold particles settled to the bottom. He separated the two phases and precipitated the silver from the solution to obtain another fine sediment. Eventually, he melted both powders and obtained, quantitatively, gold in the first case, silver in the latter.

All these experiments were of course not 'invented' by Sennert, and it is irrelevant whether he actually performed them. Yet, he was the first to connect them systematically in order to demonstrate that the reductio in pristinum statum could be used as an argument in favour of atomism. It is interesting to see that Sennert, coming to this conclusion in 1636, had to revise his former ideas concerning the transmutation of metals from the corpuscular point of view.

\subsubsection{Transmutation}

Metallic transmutation was supported by old and well documented evidence, suitable as a defense of both the Aristotelian doctrine of substantial alteration and the alchemists' quest for gold: Certain springs and rivers had the peculiar property that a piece of iron, upon being immersed for some time, turned into true copper, first at the surface, and later throughout. This process, called cementation, had been known for a very long time and had been described by scientists whose credibility was beyond any doubt. ${ }^{42}$

Few authors denied these observations, among them the Lorraine physician Nicolas Guibert, whose explanations were ridiculed by Sennert in 1629. This was not just because Sennert at that time was still an Aristotelian, but because he could rely on experimental proofs. ${ }^{43}$ However, when, in 1651, the posthumous edition of Sennert's collected works was published, the editor had to add a note found among Sennert's manuscript remains.44 In it Sennert admitted that the alleged transmutation was presumably a mere separation of copper from its vitriolic solution by means of iron, and correctly considered this process as an exchange of atoms that retain their chemical identity.

Sennert went even one step further and conceived an experiment by which the truly quantitative character of the cementation process was to be proved: One ounce of copper was dissolved in sulphuric acid to obtain the acid, blue solution of copper vitriol. Then two ounces of iron filings were added. The vessel was kept in a warm place until all of the iron had disappeared. As a result the blue colour of the solution turned colorless, and a red precipitate settled at the bottom. This precipitate was washed, 
dried, and reduced, to yield exactly one ounce of copper - the very same amount that had been dissolved originally. ${ }^{45}$ Again the method of reductio in pristinum statum was applied to demonstrate the existence of atoms. In doing so, Sennert was able to avoid the difficulties involved in explaining what happened to the properties of the metal when it 'united' with the 'salt' in solution, or whether the particles of copper, salt, and water form an essentially uniform mixture or a mere juxtaposition of parts.

Taken together, the chemical evidence presented by various authors to support the corpuscular view of matter supplied good empirical reasons for regarding natural bodies as divisible into much smaller ones that somehow retain the specific properties and can frequently be recombined to yield the original body. Yet the range and depth of experimental proofs for the atoms as such remained limited. A limited number of standard experiments was referred to more frequently in writing than repeated or extended in the laboratory. Attempts to widen the experimental basis of the corpuscular theory of matter were exceptional and barely convincing.

\section{CONCLUSION}

It is difficult to believe that arguments of this kind were capable to convince those who did not already share the atomic view of matter. Writing in the 1660's even Robert Boyle had to concede that the corpuscular hypothesis had not yet been, and probably never could be proved conclusively. ${ }^{46}$ Mere extrapolations from the visible to an underlying invisible reality were philosophically naive and epistemologically questionable. Distillations, evaporations, growth of crystals etc., were certainly appropriate for showing that something material was transferred from one place to another, but they did not prove its corpuscular nature. Although the atoms would have supplied an easy mechanism, the corpuscular interpretation of rarefaction and condensation remained questionable, since the entire problem of how the atoms interact and cohere was open, and the existence of an extended void would have had to be admitted. The introduction of a material ether disposed of these problems while creating new ones by the strange hybridization of particulate and continuous matter. Thus, as far as the experimental support for the atomic theory was concerned, the chemists and iatrochemists offered the more convincing, though by no means decisive, arguments.

By its very nature the chemical approach was pragmatic, realistic, and eclectic. The majority of chemists worked on real matter 
and real properties in a purposeful way. After all, they wanted to sell a product or to cure a patient. They simply could not afford to rely too closely upon a rigid theory, not even a corpuscular philosophy of the Boylean kind. Needless to recall that, as opposed to a stubborn historiographical myth, Boyle's clock-work universe, which provided so many fertile concepts to seventeenthcentury physics, "proved a sterile and occasionally adverse intellectual climate for an understanding of the processes underlying chemical change."47 It was not the mechanical philosophy that was to succeed in chemistry, but a non-committal, substance-oriented notion of corpuscle, something that was more like an elementary particle or a small amount of substance than a Democritean atom.

During the subsequent development of chemistry Baconian empiricism and the naive realism of the chemists were to prevail over the philosophically consistent atomism of the late seventeenth century. By the standards of Boyle's corpuscular philosophy and John Locke's insistence on the epistemological status of the corpuscles ${ }^{48}$, there was nothing of its kind throughout the eighteenth century. The new interest focussed on elements and affinity, not on atoms and motion.49 Its non-committal character was certainly not the least advantage of the kind of corpuscularianism favoured by the 'chemical' atomists. The restricted nature of its epistemological support enabled the resulting notion of corpuscle to assume whatever requirements future research was to find convenient. The traditional insistence on the ontological conformity of science and nature, the requirement of proof or falsification by means of experiment, and, what is more, the very question of the truth-value was dismissed in favour of a merely instrumental or operational link between theory and reality.

In 1661 Henry Power, the microscopist, still believed that scientific knowledge, with the help of the new instruments, would eventually advance to the very atoms and least realities of matter. "A part of Philosophy," he wrote, "but yet in discovery; and will, I fear, prove the last Leaf to be turned over in the Book of Nature." 50 To Robert Boyle, on the other hand, whose reading experience with that book was derived from 'chemical,' not microscopical observations, it was of less concern which key was the true one to decipher nature's cryptograms: Any key would do provided it made coherent sense and was fit to solve the phenomena, for which it was devised:

In the physical explications of the parts and system of the world, methinks, there is somewhat like what happens, when men conjecturally frame several keys to enable us to understand a letter written in cyphers. For though one man by his 
sagacity have found out the right key, it will be very difficult for him, to prove otherwise than by trial, that this or that word is not such, as it is guessed to be by others, according to their keys; [ ... ] yet, if due trial being made, the key he proposes, shall be found so agreeable to the characters of the letter, as to enable one to understand them, and make a coherent sense of them, its suitableness to what it should decypher, is, without confutations, or extraneous positive proofs, sufficient to make it be accepted as the right key of that cypher.51

Due to its tentative nature the corpuscular hypothesis was even more viable than any rigid theory or ontological determination ever would have been. Its directing influence on future research was founded less on immediate results, than - as it was not uncommon in early modern science - on the basis of hope and promise. It was not until John Dalton's chemical atomism in the early nineteenth century, however, that this promise was to be fulfilled.

Institut für Geschichte der

Naturwissenschaften, Mathematik und Technik

Universität Hamburg

\section{NOTES}

1. In particular Kurd Lasswitz, Geschichte der Atomistik vom Mittelalter bis Newton, 2 vols. (Hamburg/Leipzig 1890).

2. Hélène Metzger, Les doctrines chimiques en France du début du XVIIe à la fin du XVIIIe siècle [1923] (Paris: Blanchard, 1969); G. B. Stones, "The Atomic View of Matter in the XVth, XVIth, and XVIIth Centuries," Isis 10 (1928), 445-465; Marie Boas, "The Establishment of the Mechanical Philosophy," Osiris 10 (1952), 412-541; Stephen Toulmin and June Goodfield, The Architecture of Matter [1962] (Chicago/London: University of Chicago Press, 1982), pp. 137-200; Ugo Baldini, "Il corpuscolarismo italiano del Seicento: Problemi di metodo e prospettive di ricerca," in: Ricerche sull'atomismo del Seicento, Pubblicazioni del "Centro di Studi del Pensiero Filosofico del Cinquecento e del Seicento in Relazione ai Problemi della Scienza' I,9 (Firenze: Nuova Italia, 1977), pp. 1-76.

3. Lucr. IV, 116-122.

4. Lucr. II, 114-131.

5. Claudius Berigardus, Circulus Pisanus de veteri et peripatetica philosophia [1643] (Padova 1661), IV.8., pp. 421-422. 
6. Daniel Sennertus, Hypomnemata Physica [1636], in: Danielis Sennerti Opera Omnia, vol. I (Lyon 1656), pp. 100-172, Hypomnema III. De atomis et mistione 1.1., p. 118.

7. Lucr. II, 391-397.

8. Iohannes Chrysostomus Magnenus, Democritus reviviscens sive vita et philosophia Democriti (Leyden 1648), p. 206-207; see also Alfred Stückelberger, Antike Atomphysik: Texte zur antiken Atomlehre und ihrer Wiederaufnahme in der Neuzeit (München: Heimeran, 1979), p. 282-285.

9. Walter Charleton, Physiologia Epicuro-Gassendo-Charltoniana (London 1654), II.4., p. 114.

10. Petrus Gassendi, Syntagma philosophicum, in: Petri Gassendi Opera omnia in sex tomos divisa, Vol. I (Lyon 1658), I.3.5., p. 265.

11. Alfred Stückelberger, "Lucretius reviviscens: Von der antiken zur neuzeitlichen Atomphysik," Archiv für Kulturgeschichte 54 (1972), 1-25, here on p. 19: "Zum erstenmal ist hier in der Geschichte der Atomphysik der Schritt vom qualitativen zum quantitativen Denken gemacht worden, mit einer übrigens durchaus brauchbaren Methode - später sind allgemeine Atomgewichte durch Gase errechnet worden -, die auch zu einer erstaunlich zutreffenden Größenordnung führt: er errechnet eine Anzahl von ca. 7,7-1019 Atomen in einem Weihrauchkorn;" cf. idem, Antike Atomphysik (cit. n. 8), p. 60.

12. Jacobus Gaffarellus, Curiositez inouyez, hoc est: Curiositates inauditae [1629] (Hamburg/Amsterdam 1678), pp. 97-99; see also Lynn Thorndike, History of Magic and Experimental Science, vol. VII (New York: Columbia University Press, 1958), pp. 304-309.

13. Iosephus Quercetanus, Ad veritatem Hermeticae medicinae ... responsio (Paris 1604), pp. 292-294.

14. See Correspondance du P. Marin Mersenne, ed. by Marie Tannery and Cornelis de Waard, vol. I (Paris: Presses Universitaires, $1945)$, p. 326.

15. Petrus Gassendi, Animadversiones in decimum librum Diogenis Laertii, 2 vols. (Lyon 1649), I, p. 207; and verbatim also in idem, Syntagma philosophicum (cit. n. 10), I.3.6., p. 268-269.

16. Henry Power, Experimental Philosophy ... in Avouchement and Illustration of the now famous Atomical Hypothesis (London 1664), part I, sig. b2r, c2v-[c3r].

17. Ibid., observ. 34, p. 43.

18. Ibid., observ. 35 , p. 44.

19. Ibid., p. 51.

20. Hans Kangro, "Erklärungswert und Schwierigkeiten der Atomhypothese und ihrer Anwendung auf chemische Probleme in der 
ersten Hälfte des 17. Jahrhunderts," Technikgeschichte 35 (1968), 13-36, here p. 20.

21. Lucr. I, 298-299.

22. Lucr. I, 305-310.

23. Edward Grant, Much Ado About Nothing: Theories of Space and Vacuum from the Middle Ages to the Scientific Revolution (Cambridge/London/New York: Cambridge University Press, 1981).

24. Arist., Phys. IV.6. (213b21-22).

25. Francis Bacon, Sylva Sylvarum, I.34. [1627], in: The Works of Francis Bacon, ed. by James Spedding, Robert Leslie Ellis, and Douglas Denon Heath, Vol. II (London 1859), p. 354.

26. Gassendi, Syntagma philosophicum (cit. n. 10), I.2.3., p. 195; see also ibid., p. 196.

27. Ibid., p. 195.

28. Johannes Baptista Morinus, De atomis et vacuo contra Petri Gassendi Philosophiam Epicuream (Paris 1650), p. 19-20.

29. Lucr. I, 385-397.

30. Galileo Galilei, Discorsi e dimostrazioni matematiche [1638], in: Le Opere di Galileo Galilei, Edizione Nazionale, vol. VIII (Firenze: Barbera, 1965), p. 59.

31. Ibid., p. 62-63.

32. Arist., Phys. IV.9. (217a20-b19).

33. Gassendi, Animadversiones (cit. n. 15), I, pp. 424-444.

34. For his sponge-like concept of rarefaction see Renatus Descartes, Principia philosophiae [1644], II.6.-7., in: Oeuvres de Descartes, ed. by Charles Adam and Paul Tannery, vol. VIII/1 (Paris : Vrin, 1982), pp. 43-44. See also Boas, "Mechanical Philosophy" (cit. n. 2), pp. 442-460.

35. See W. Subow, "Zur Geschichte des Kampfes zwischen dem Atomismus und dem Aristotelismus im 17. Jahrhundert (Minima naturalia und Mixtio)," in: Sowjetische Beiträge zur Geschichte der Naturwissenschaft, ed. by Gerhard Harig (Berlin: Deutscher Verlag der Wissenschaften, 1960), pp. 161-191; Norma E. Emerton, The Scientific Reinterpretation of Form, Cornell History of Science Series (Ithaca/London: Cornell University Press, 1984), esp. pp. 76-105.

36. R. Hooykaas, "The Discrimination between 'natural' and 'artificial' Substances and the Development of Corpuscular Theory," Archives Internationales d'Histoire des Sciences 1 (1948), 640-651, here on p. 643; idem, "The Experimental Origin of Chemical Atomic and Molecular Theory before Boyle," Chymia 2 (1949), 65-80, here on p. 77.

37. Daniel Sennertus, De consensu et dissensu Galenicorum et Peripateticorum cum Chymicis [1619], in Opera omnia (cit. n. 6), p. 230; see also Tullio Gregory, "Studi sull'atomismo del 
Seicento, II: David van Goorle e Daniel Sennert," Giornale critico della Filosofia Italiana 45 (1966), 44-63, here on pp. 53-55.

38. Angelus Sala, Anatomia vitrioli [1609], 3rd. ed. (Leyden 1617), pp. 96-97.

39. Angelus Sala, Chrysologia seu examen auri chymicum (Hamburg 1622), III.6.5., sig. K3r, F6v-7r.

40. Sennertus, Hypomnema III.1.1. (cit. n. 6), p. 118.

41. Ibid., p. 118-119.

42. E.g. Georgius Agricola, De natura fossilium, ed. by Georgius Fabricius (Wittenberg 161'), IX.2., p. 701.

43. Sennertus, De consensu et dissensu (cit. n. 38), II, p. 182. 44. Ibid., Preface to the reader.

45. Ibid., II, p. 182.

46. William Arthur Drumin, The Corpuscular Philosophy of Robert Boyle: Its Establishment and Verification, Ph.D. thesis, Columbia University, 1973, esp. pp. 79-83; see also Robert Boyle, "A Physico-Chymical Essay," in: Certain Physiological Essays [1661], in: The Works of the Honourable Robert Boyle, ed. by Thomas Birch, vol. I (London 1772), pp. 359-376, here on p. 375.

47. Thomas S. Kuhn, "Robert Boyle and Structural Chemistry in the Seventeenth Century," Isis 43 (1952), 12-36, here on p. 15; see also Boas, "Mechanical Philosophy" (cit. n. 2), pp. 494499.

48. Peter Alexander, Ideas, Qualities and Corpuscles: Locke and Boyle on the External World (Cambridge/London/New York: Cambridge University Press, 1985).

49. Boas, "Mechanical Philosophy" (cit. n. 2), pp. 505-520; Arnold Thackray, Atoms and Powers: An Essay on Newtonian MatterTheory and the Development of Chemistry, Harvard Monographs in the History of Science (Cambridge, Mass.: Harvard University Press, 1970).

50. Power, Experimental Philosophy (cit. n. 16), I, p. 58.

51. Robert Boyle, About the Excellency and Grounds of the Mechanical Hypothesis [1674, written ca. 1665], in: The Works (cit. n. 46), IV, pp. 67-78, here on p. 77. 